\title{
CALIBRATION PROCEDURE AND UNCERTAINTY ANALYSIS OF AN ELECTRONIC SCALE BASED ON TWO-CURRENT SOURCE SUPPLIED CIRCUIT
}

\author{
Wojciech Walendziuk, Adam Idzkowski
}

Original scientific paper

The article presents the prototype version of an original weight scale in which a non-conventional supplying circuit of strain gauge load cells is applied The paper discusses construction of an electrical circuit, the way of strain gauge transducer connection and the measuring procedure. As far as the authors know, this novel electrical circuit and its application in a weight scale system have never been mentioned in literature. The specifications for directreading weight scales typically include readability, repeatability, linearity and eccentricity. The values of these parameters were estimated and used for calculation of the weight measurement uncertainty in the tested measuring range of the designed device.

Keywords: measurement uncertainty; strain measurement; weight measurement

\section{Postupak baždarenja i analiza nesigurnosti elektronske vage na temelju strujnog kruga istosmjerne i izmjenične struje}

Izvorni znanstveni članak

Rad predstavlja verziju prototipa originalne vage u kojoj je primijenjeno neuobičajeno napajanje ćelija tenziometra. U radu se razmatra konstrukcija električnog strujnog kruga, način povezivanja pretvarača tenziometra i postupak mjerenja. Koliko je autorima poznato, taj novi električni krug i njegova primjena na sustav vage nisu do sada spomenuti u literaturi. Specifikacije za vage s direktnim očitavanjem tipično uključuju čitljivost, ponovljivost, linearnost i ekscentričnost. Procijenjene su vrijednosti tih parametara i primijenjene u proračunu nesigurnosti mjerenja težine u ispitivanom rasponu mjerenja konstruiranog uređaja.

Ključne riječi: nesigurnost mjerenja; mjerenje deformacije; mjerenje težine

\section{Introduction}

The purpose of this paper is to present an original electrical circuit with four resistance strain gauges which were applied in the patient's weight measurement device. The use of another, original type of supply in the weight scale allows to conduct a measurement in a simple way. The value of the sought mass in this prototype device is calculated and visualized with the use of LabVIEW program. The presented weight measurement device was developed on the basis of another version of the device, presented in paper [1], which was supplied by the voltage divider circuit.

Other resistance input signal conditioners were tested on the example of two-parameter simultaneous measurement of resistance increments of the four-terminal (4T) circuit [2]. Two types of unconventional circuit structures for strain measurement and for the primary signal conditioning on the input analogue part of instrumentation channels were presented in literature. One of them is a circuit of two four-arm classic bridges connected in cascade [3]. The other one has an unconventional supplying: the 4T circuit is supplied by two equal current sources $\mathrm{J}$ connected to opposite arms $2 \mathrm{~J}$ which is realized by switching over two equal sources between these arms $-2 \times 2 \mathrm{~J}$. In some cases only one current supply can be used $-2 \times 1 \mathrm{~J}$ [4].

The purpose of this paper is to discuss the issue of uncertainty in the measurement done with the use of a prototype weight scale in a selected measuring range. The range of $20 \mathrm{~kg}$ was selected due to the fact that the reference weights of a maximum mass of $20 \mathrm{~kg}$ were available. Moreover, a method of assigning uncertainty based on the data determined during a calibration [5] (readability, repeatability, linearity, eccentricity) is also presented.

\section{Measurement system}

The measurement system was implemented in the platform where an one-sidedly fixed beam was placed in the corners (Fig. 1). The strain was examined for each of the cantilever beams. They were all equipped with a strain gauge circuit, which enabled calculating the applied load.

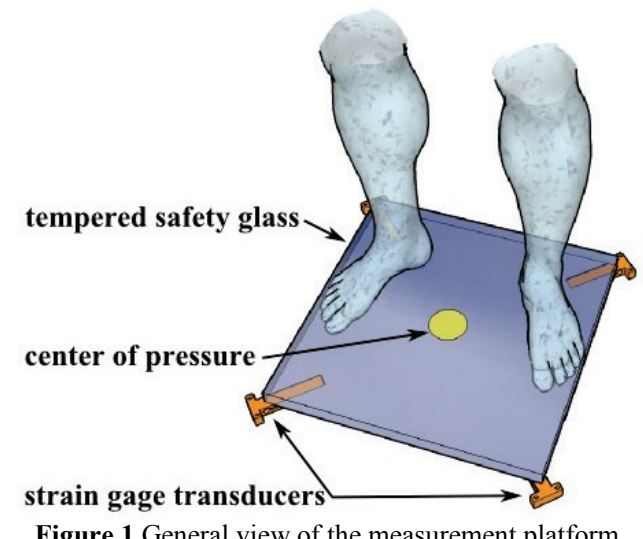

Strain gauge transducers $T_{1}, T_{2}, T_{3}, T_{4}$, were supplied by the circuit in which electronic keys $K_{1}, K_{2}, K_{3}, K_{4}$ were used. As shown in Fig. 2, the opposite arms of the bridge power supply include two DC current sources $J_{1}=J_{2}=J$ and auxiliary resistors $R_{5}, R_{6}$.

The complete bridge system consists of two current sources, two resistors, four strain gauge sensors (TF$3 / 120$, Tenmex) and four electronic keys. General overview of the laboratory tested device is presented in Fig. 3.

The principle of operation of the two-current source supplied signal conditioner is based on switching appropriate parts of the circuit and sub sequentially measuring voltage in points $A, B, C, D$ [6]. In this way 
successive voltage values can be obtained and the mass can be calculated with the use of the following algorithm.

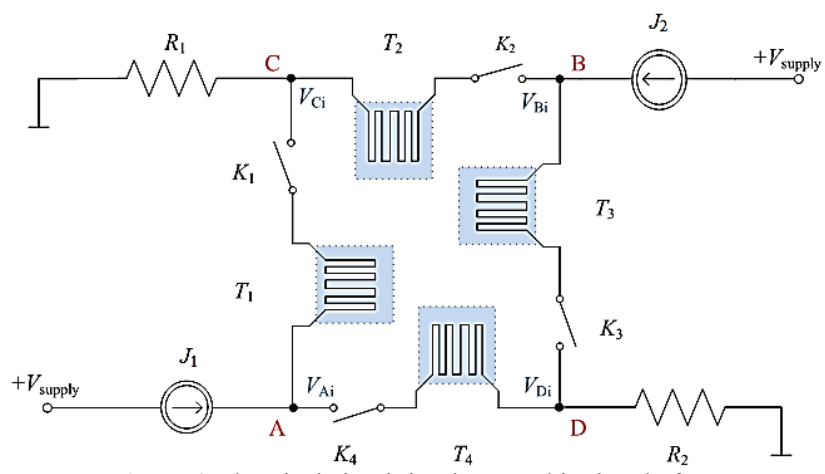

Figure 2 Electrical circuit implemented in the platform

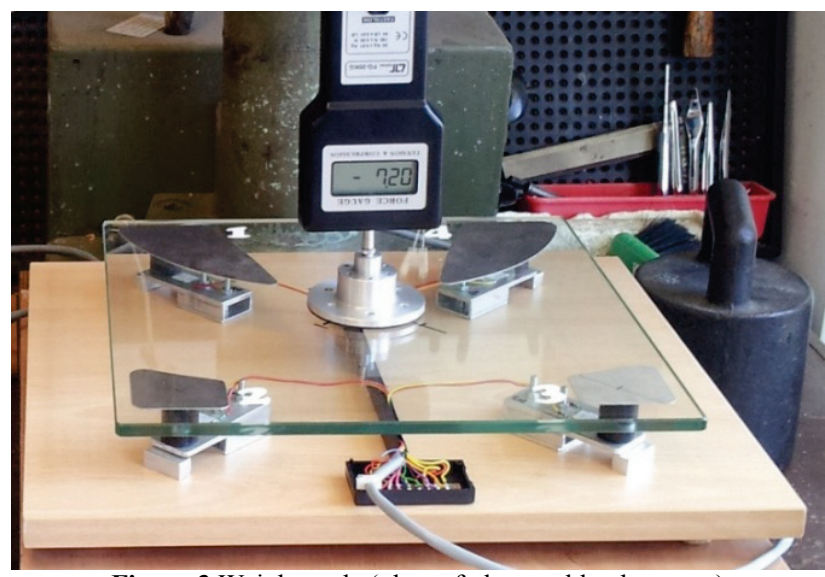

Figure 3 Weight scale (plate of glass and load sensors)

In each measurement cycle $i$, with the use of suitable enabling 1 or disabling 0 state of the electronic keys $K_{1}$ to $K_{4}$, it is possible to measure voltage values for determining the expected load. The first step is to tare the platform in two measurement cycles. In this step the voltages $V_{\mathrm{A} i 0} \ldots V_{\mathrm{D} i 0}$ are stored and held in memory.

The second step allows determining a mass applied to the platform. In this step the voltages $V_{\mathrm{A} i} \ldots V_{\mathrm{D} i}$ are measured. It is done alternately - by the same, two combinations of electronic keys. The resistance increments $\Delta R_{1}, \Delta R_{2}, \Delta R_{3}, \Delta R_{4}$ are calculated from Eqs. (1) to (4) in two cycles:

Cycle 1: $K_{1}=0, K_{2}=1, K_{3}=0, K_{4}=1$

$$
\begin{aligned}
& \Delta R_{2}=\frac{\left(V_{B 1}-V_{C 1}\right)-\left(V_{B 10}-V_{C 10}\right)}{J}, \\
& \Delta R_{4}=\frac{\left(V_{A 1}-V_{D 1}\right)-\left(V_{A 10}-V_{D 10}\right)}{J},
\end{aligned}
$$

Cycle 2: $K_{1}=1, K_{2}=0, K_{3}=1, K_{4}=0$

$$
\begin{aligned}
& \Delta R_{1}=\frac{\left(V_{A 2}-V_{C 2}\right)-\left(V_{A 20}-V_{C 20}\right)}{J}, \\
& \Delta R_{3}=\frac{\left(V_{B 2}-V_{D 2}\right)-\left(V_{B 20}-V_{D 20}\right)}{J} .
\end{aligned}
$$

Having all resistance increments calculated, it is possible to determine their sum:
$\Delta R_{m}=\Delta R_{1}+\Delta R_{2}+\Delta R_{3}+\Delta R_{4}$

Taking it into consideration, the relation between the resultant load and the sum of resistance increments can be used to determine the mass. It should be stressed that the vertical force (resultant load) acting against the platform is a sum of component forces (loads) in each corner of the plate. Therefore an indicated mass was calculated according to the following formula:

$m=c_{f} \Delta R_{m}+m_{t}$,

where: $c_{f}$ - is a calibration factor of weight scale; $m_{t}$ - tare mass.

By using software and an analog-to-digital converter, (ADC) a zero and a calibration sample is digitized just prior and just after a test load. The average ADC value is computed for the zero and for the calibration samples. The zero sample average is subtracted from the calibration sample average and this delta ADC value is used to determine the calibration factor.The analysed range of device is $20 \mathrm{~kg}$. The weight scale requires an external mass (test load) to perform self-calibration.

\section{Calibration procedure of the weight scale}

Several tests should be conducted in order to evaluate quality of the weight scale. One of them takes into consideration repeatability of measurement. This test can give information about i.e. the relaxation time of the force sensors. Other tests (linearity and eccentricity) give information about sensors characteristics and methods of their linearization. During examination the indication error and uncertainty should be also calculated.

The error of indication of a weight scale is a difference between indication $m$ (measured value of mass) and reference value of mass $m_{\text {ref }}$. The basic formula [5] for calibration is:

$E=m-m_{\text {ref }}$.

The variance of error of indication is:

$u^{2}(E)=u^{2}(m)+u^{2}\left(m_{\text {ref }}\right)$.

The uncertainty of reference value of mass $u\left(m_{\text {ref }}\right)$ will not be considered in this paper. It is assigned in the laboratories and contains the corrections due to air buoyancy, convection, drift and other factors [5], [9], [13]. The standard test loads (class $\mathrm{M}_{2}$ ) that comply with the relevant specifications [8] were used. Assuming that

$u\left(m_{\text {ref }}\right)<<u(m)$

standard uncertainty of calibration error is equal to standard uncertainty of indication of the weight scale

$u(E)=u(m)$

Uncertainty determination was based on the combination of the measured data. It is presented in the following part of this paper. 


\subsection{Readability test}

Considering electronic and digital scales, readability is the smallest change in mass that corresponds to the change in the displayed value. In presented research, a result value has two decimal points. It means that readability $d$ is $0,01 \mathrm{~kg}$. It should not be confused with accuracy. When properly calibrated, most scales will be accurate to within \pm 4 scale divisions $d$.

\subsection{Repeatability test}

Repeatability tests were performed with a test load of about $50 \%$ of calibration range [5]. The test load was placed in the center of the platform. Measurements were done in 10 steps every 30 seconds.

One repeatability test consisted of 10 measurements (Tab. 1). During the test the value of standard deviation [6] was calculated according to the following formula:

$$
s(m)=\sqrt{\frac{\sum_{j=1}^{N}\left(m_{j}-\bar{m}\right)^{2}}{N-1}},
$$

where: $m_{j}$ - value $j$ of measured mass; $\bar{m}$ - mean mass; $N$ - number of samples $(N=10)$.

Table 1Repeatability test

\begin{tabular}{|c|c|}
\hline Reading number $(j)$ & Measured value of mass $m_{j}(\mathrm{~kg})$ \\
\hline 1 & 9,020 \\
\hline 2 & 8,810 \\
\hline 3 & 8,590 \\
\hline 4 & 8,590 \\
\hline 5 & 8,810 \\
\hline 6 & 8,590 \\
\hline 7 & 8,370 \\
\hline 8 & 8,370 \\
\hline 9 & 8,810 \\
\hline 10 & 8,590 \\
\hline Standard deviations $(m)$ & 0,205 \\
\hline
\end{tabular}

\subsection{Linearity test}

Formula (7) is true for a single measurement. An indication $I$ in whole measuring range should be a linear function of reference value of mass $m_{\text {ref. }} E_{\text {appr }}$ are the differences between observed and referenced values of mass. For each $m$-value of test load $M$ in whole measuring range the approximation error $E_{\text {appr }}$ is:

$E_{\text {appr } \_k}=m_{k}-a \cdot m_{\text {ref } \_k}-b$,

where: $a, b$ are the parameters of referenced, linear function, $k=1, \ldots, M$.

Uncertainty of the approximation error (residual standard deviation) is:

$u\left(E_{\text {appr } \__{k}}\right)=\sqrt{\frac{\sum_{k=1}^{M}\left(E_{\text {appr } \__{-}}\right)^{2}}{M-2}}$ where: $M$ - number of test loads $(M=7)$. The results of linearity test are presented in Tab. 2 .

Further step of the research was to estimate simple linear regression. An alternative solution is to implement a non-linear calibration algorithm (adaptive segmenting best-fitting method) with polynomial set, as it is presented in [10].

Table 2 Linearity test

\begin{tabular}{|c|c|c|}
\hline$k$ & $\begin{array}{c}\text { Reference value of mass } \\
m_{\text {ref } \_}(\mathrm{kg})\end{array}$ & $\begin{array}{c}\text { Measured value of mass } \\
m_{k}(\mathrm{~kg})\end{array}$ \\
\hline 1 & 0,00 & $-0,26$ \\
\hline 2 & 0,50 & 0,62 \\
\hline 3 & 1,00 & 1,23 \\
\hline 4 & 2,00 & 2,10 \\
\hline 5 & 5,00 & 5,13 \\
\hline 6 & 10,00 & 9,88 \\
\hline 7 & 20,00 & 20,26 \\
\hline & $\begin{array}{c}\text { Uncertainty of } \\
\text { approximation error } u_{\text {appr }}\end{array}$ & 0,196 \\
\hline
\end{tabular}

\subsection{Eccentricity test (corner loading)}

Eccentricity error $E_{\mathrm{e}}$ is a maximum absolute difference between indication when a test load is put at the central point of the weighing platform CNTR, and indication when the same mass standard is located at another place on the weighing platform BL, BR, FL or FR (Fig. 4).

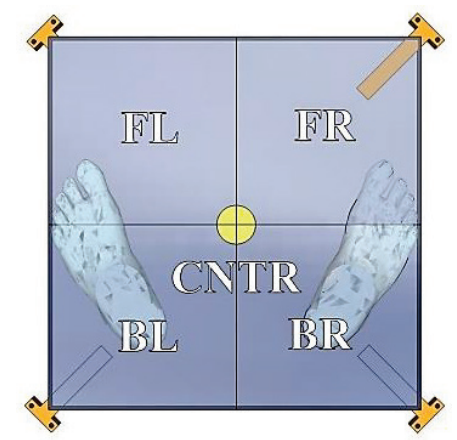

Figure 4 Pressure zones of the measurement platform

For single-range weight scales a test load should equal $50 \%$ of maximum load. The measured data of eccentricity test is presented in Tab. 3 .

Table 3 Corner loading (Eccentricity)

\begin{tabular}{|c|c|c|}
\hline Quadrant & $\begin{array}{c}\text { Measured value } \\
\text { of mass }(\mathrm{kg})\end{array}$ & $\begin{array}{c}\text { Absolute } \\
\text { difference }(\mathrm{kg})\end{array}$ \\
\hline CNTR & 9,88 & - \\
\hline BL & 10,80 & $0,92\left(E_{\mathrm{e}}\right)$ \\
\hline BR & 8,98 & 0,90 \\
\hline FL & 10,53 & 0,65 \\
\hline FR & 9,24 & 0,64 \\
\hline
\end{tabular}

\section{Uncertainty calculation}

The uncertainty calculations are based on the JCGM Guide [7] and the corresponding EURAMET document [5]. Uncertainty is evaluated either by the Type A or by the Type B method of evaluation. Type A is based on a statistical analysis of a series of measurements. Type B evaluation is strictly connected with systematic errors and knowledge of the instrument and its accuracy. Taking it 
into account, the measured data allowed calculating the expanded uncertainty in whole measuring range of the designed device.

The contributed uncertainties shown in Tab. 4 are:

- the standard uncertainty of weighing process (standard deviation of the mass difference), Type A;

- uncertainty due to display resolution of a digital weight scale (readability), Type B;

- uncertainty due to eccentric loading, Type B;
- uncertainty of approximation error, Type B.

The uncertainties which were not taken into account in the calculations:

- uncertainty of reference mass, Type B;

- uncertainty of the air buoyancy correction, Type B;

- uncertainty due to sensitivity of the weight scale (influence of temperature and load), type B.

Table 4 Budget of uncertainty of measured mass in a measuring range of $20 \mathrm{~kg}$

\begin{tabular}{|l|c|c|c|}
\hline \multicolumn{1}{|c|}{ Source of uncertainty } & Standard uncertainty & $\begin{array}{c}\text { Probability } \\
\text { distribution }\end{array}$ & Sensitivity coefficient \\
Readability (Type B) & $u_{\mathrm{d}}$ & square & 1 \\
\hline Repeatability(Type A) & $s(m)$ & normal & 0,000008 \\
\hline Approximation error $E_{\text {appr }}($ Type B) & $u_{\text {appr }}$ & square & 0,042025 \\
\hline Eccentricity error $E_{\mathrm{e}}($ Type B) & $u_{\mathrm{e}}$ & square & 1 \\
\hline Combined standard uncertainty $u(E)$ & & 0,012805 \\
\hline Expanded uncertainty $U($ for: $k=2, p=95 \%)$ & $\pm 0,282133$ \\
\hline
\end{tabular}

According to $[5,7,8]$ expanded uncertainty can be written as:

$$
\begin{aligned}
& U=k \cdot u(E)=k \sqrt{u_{\mathrm{d}}^{2}+s(m)^{2}+u_{\mathrm{appr}}^{2}+u_{\mathrm{e}}^{2}}= \\
& =k \sqrt{\left(\frac{d}{2 \sqrt{3}}\right)^{2}+s(m)^{2}+\left(\frac{u\left(E_{\mathrm{appr}}\right)}{\sqrt{3}}\right)^{2}+\left(\frac{E_{\mathrm{e}}}{\sqrt{3}}\right)^{2}} .
\end{aligned}
$$

To calculate $U$, readability $d=0,01 \mathrm{~kg}$, as well as the values of $s(m), u_{\mathrm{appr}}$ and $E_{\mathrm{e}}$ from Tabs. $1 \div 3$ were introduced.

As it can be observed in Tab. 4, eccentricity, which is greater than repeatability of the device, has the largest contribution in the budget of uncertainty. It cannot be omitted by improving the mechanical construction of the device.

\section{Conclusions}

An idea of a digital weight scale based on original electrical supplying circuit was presented. The sources of uncertainty during calibration were quoted. Standard and expanded uncertainties of measured mass were calculated. For whole device range of $20 \mathrm{~kg}$ :

- $\quad$ expanded uncertainty $U(k=2, p=95 \%)$ is $\pm 1,16 \mathrm{~kg}$ (Tab. 4),

- $\quad$ expanded uncertainty $U(k=2, p=95 \%)$ is $\pm 0,46 \mathrm{~kg}$ (if eccentricity test is not included).

The main sources of the uncertainties come from inaccuracies of strain gauge sensor construction which should be improved in further research.

This research is connected with an implementation of this solution of the weight measurement system into the force platform. Such devices are used in the measurements of ground reaction forces [11, 12]. The system will be integrated with a PC with the use of the LabVIEW software.

\section{Acknowledgements}

This work was supported by Bialystok Technical
University research grant No S/WE/1/2013.

\section{References}

[1] Idzkowski, A.; Walendziuk, W. Evaluation of the Static Posturograph Platform Accuracy. // Journal of Vibroengineering. 11, 3(2009), pp. 511-516.

[2] Warsza, Z. L. Two parameter (2D) measurements in double-current supply four-terminal resistance circuits. // Metrology and Measurement Systems. 13 (1), 2006, pp. 4965.

[3] Warsza, Z. L. Backgrounds of two variable (2D) measurements of resistance increments by bridge cascade circuit. // Proc. of SPIE, Photonics Applications in Astronomy, Communications, Industry, and High-Energy Physics Experiments, vol. 6347, part 2, 63472R, 2006. DOI: 10.1117/12.714768

[4] Idzkowski, A.; Walendziuk, W.; Warsza, Z. L. Unconventional Double-Current Circuit for Deflection and Temperature Simultaneous Measurement. // Elektronikair Elektrotechnika (Electronics and Electrical Engineering). 21, 1(2015), pp. 23-27. DOI: 10.5755/j01.eee.21.1.6834

[5] Guidelines on the Calibration of Non-Automatic Weighing Instruments, EURAMET/cg-18/v.02, 2009.

[6] Walendziuk, W.; Idzkowski, A.; Golebiowski, J. Reconfigurable Two-Current Source Supplied Signal Conditioner for Resistive Sensors. // Elektronikair Elektrotechnika (Electronics and Electrical Engineering). 22, 2(2016), pp. 27-32. DOI: 10.5755/j01.eie.22.2.14587

[7] Evaluation of measurement data - Guide to the expression of uncertainty in measurement, JCGM (Joint Committee of Guides in Metrology), 2008.

[8] International Recommendation OIML R111, Weights of Classes E1, E2, F1, F2, M1, M1-2, M2, M2-3, M3, 2004.

[9] Valcu, A.; Baicu, S. Analysis of the results obtained in the calibration of electronic analytical balances. // EPE (IEEE) Proceedings of the International Conference and Exposition on Electrical and Power Engineering / 2012, pp. 861-866.

[10] Shenshen, Gu.; Wentao, Zhang.; Fei, Wang; Lili, Zhang; Zhijian, Chen. Nonlinear Calibration of Resistance Strain Type Electronic Balance and Its Application in Industrial Sorting System. $/ / 8^{\text {th }}$ IEEE Conference on Industrial Electronics and Applications (ICIEA) / 2013, pp. 18441849.

[11] Derlatka, M. Human Gait Recognition Based on Signals from Two Force Plates. // Lecture Notes in Computer Science, vol. 7268: Artificial Intelligence and Soft 
Computing, Springer-Verlag. (2012), pp. 251-258. DOI: 10.1007/978-3-642-29350-4_30

[12] Bartlett, H. L.; Ting, L. H.; Bingham, J. T. Accuracy of force and center of pressure measures of the Wii Balance Board. // Gait and Posture. 39, 1(2014), pp. 224-228. DOI: 10.1016/j.gaitpost.2013.07.010

[13] Reichmuth, A.; Wunderli, S.; Weber, M.; Meyer, V. R. The uncertainty of weighing data obtained with electronic analytical balances. // Microchim. Acta. 148, (2004), pp. 133-141. DOI: 10.1007/s00604-004-0278-3

\section{Authors' addresses}

Wojciech Walendziuk, Assistant Professor Ph.D.

Bialystok University of Technology

Department of Electrical Engineering

ul. Wiejska 45D, Bialystok, Poland

E-mail: w.walendziuk@pb.edu.pl

Adam Idzkowski, Assistant Professor Ph.D.

Bialystok University of Technology

Department of Electrical Engineering

ul. Wiejska 45D, Bialystok, Poland

E-mail: a.idzkowski@pb.edu.pl 